\title{
The Relationship between Trade Openness and Economic Growth: The Case of BRICS Countries
}

\author{
Varaidzo Batsirai Shayanewako* \\ Department of Economics, University of Fort Hare, South Africa
}

\begin{abstract}
Since their inception in 2006, the BRICS countries (Federative Republic of Brazil, the Russian Federation, the Republic of India, the People's Republic of China and the Republic of South Africa) have been fully committed to the strengthening and expansion of trade and investment ties between member states and the international world. However, it is important to empirically analyse whether the growth of these economies is driven by trade because the extensive trade -growth studies have yielded mixed and inconclusive empirical results. Therefore, this study is an empirical attempt to investigate the relationship between trade openness and economic growth in the BRICS counties by utilizing the Autoregressive Distributed Lag (ARDL) bounds test to cointegration and the Granger causality tests for the period from 1990 to 2017. The presence of a long run relationship between trade openness and economic growth is confirmed in this study. Evidence from the bounds test of cointegration indicate that there exists a bi-directional causality from trade openness to economic growth in the BRICS countries. Furthermore, this study provides evidence of a unidirectional causality between trade openness and output growth, particularly in the case of China.
\end{abstract}

Keywords: Trade and investment; International markets; Domestic currency; Economic growth; Exports and imports

\section{Introduction}

Since its inception in 2006, the BRICS countries (Federative Republic of Brazil, the Russian Federation, the Republic of India, the People's Republic of China and the Republic of South Africa) has been fully committed to the strengthening and expansion of trade and investment ties between member states and the international world. These countries have placed great emphasis on infrastructural development facilitated by the BRICS development Bank and fully utilising the myriad of import and export opportunities presented by the collaborative efforts of these economies [1]. Their trade policies have been for long oriented towards regional trade cooperation and expansion into the international markets. This has resulted in increased trade between BRICS countries by 70\% between 2009 and 2015 [2]. As a result, the trade and investment opportunities associated with BRICS nations are as vast as they are promising. However, the question is whether trade is a catalyst of economic growth, as maintained by the trade-led growth hypothesis, in these countries.

The literature on the trade-growth link is two-sided. The first strand of literature supports the notion that trade stimulates longterm economic growth [3-6]. These empirical studies envisage that the positive trade-growth link is supported by the fact that openness to trade has the potential to enhance access to goods and services, efficient allocation of resources and enhanced total factor productivity via the diffusion of technology and the spill over of knowledge. Put differently, economies which are highly subjected to trade openness experience high growth rates than those with less openness to trade. According to this perspective, developing economies stand to gain more by engaging in trade with advanced economies because more outwardoriented economies record higher economic growth rates. According to Stiglitz [7] and World Bank [2], for example, the positive effect of trade openness on economic growth can be traced back to the early growth of the East Asian economies. Simply put, this first strand of literature strongly supports the trade-growth hypothesis.

On the other hand, another body of literature argue that the tradegrowth link does not exist. This is supported by previous studies [810]. This strand of research argues that an increase in openness to trade could be growth retarding by increasing the prices of goods and services and depreciating the value of the domestic currency. This is particularly more pronounced in economies that specialises in the production and exportation of primary products that are competitively of low quality and subject to shocks of terms of trade [9]. Nevertheless, regardless of the conflicting views on the trade-growth nexus, the main theme running through the literature is that trade is the engine of economic growth in the long run and this has made significant contributions to the growth of many economies. Consequently, it is important to understand the extent to which the trade-growth link holds in the case of the BRICS countries since mixed and inconclusive results exist regarding this important hypothesis.

This particular study contributes to the existing body of knowledge in respect to the empirical understanding of the trade-growth link in a number of ways. For one, unlike other previous studies that have investigated this hypothesis using a specific country analysis $[4-6,11,12]$ this study uses a cross-sectional homogeneity assumption to analyse the relationship between trade openness and economic growth in the BRICS family of countries. This is important than a single-country analysis because panel data regression approaches applied in this study impose cross-sectional homogeneity on coefficients, with the hope that the results could be inferred to other emerging and developing economies since, in spite of the fact that these economies are not on the same level of growth and integration with the world economy, no much difference exists on trade openness. Furthermore, the main distinctive characteristic of this paper on this issue lies on the use of additional explanatory variables such as capital, foreign direct investment and

*Corresponding author: Varaidzo Batsirai Shayanewako, Department of Economics, University of Fort Hare, South Africa, Tel: +27406022011; E-mail: vbshayanewako@live.co.za

Received April 02, 2018; Accepted April 09, 2018; Published April 16, 2018

Citation: Shayanewako VB (2018) The Relationship between Trade Openness and Economic Growth: The Case of BRICS Countries. J Glob Econ 6: 289. doi: 10.4172/2375-4389.1000289

Copyright: (c) 2018 Shayanewako VB. This is an open-access article distributed under the terms of the Creative Commons Attribution License, which permits unrestricted use, distribution, and reproduction in any medium, provided the original author and source are credited. 
labour into the econometric model by employing the Autoregressive Distributed Lag (ARDL) bounds test to cointegration.

The remainder of the paper is structured as follows: The following Section presents the overview of trade and growth in the BRICS economies. Section three provides the literature review upon which this study is built. The theoretical framework and the methodology is presented in Section four and Section five provides the empirical results and discussion. The last Section presents the conclusion and policy implications of the study.

\section{Literature Review}

The literature on the relationship between trade openness and economic growth, although with mixed empirical results, is richly documented on both the theoretical and empirical platforms. The trade-growth link is best exposed by the comparative advantage and the endogenous growth theories. The trade liberalization and the imitation cost perspective extensively extends the understanding of the tradegrowth nexus. The comparative advantage theory maintains that an economy specializes in the production of a product or service in which it has comparatively better factor endowments than its trading partner [11]. Consequently, the production and exportation of that product or service will increase resulting in increased economic growth. Markus and Daniel [13] extended this theory by arguing that economic growth and productivity are a result of trade liberalization by specializing on sectors with economies of scale. The endogenous growth theory asserts that there exists a strong positive trade-growth link as a result of advancement in international technology and dissemination of technical knowledge $[14,15]$. This theory holds that greater openness to trade provides greater access to international advanced technology and increased output growth. Another important determinant of the trade-growth hypothesis is the cost of imitation. If the imitation cost of innovation in developing economies is lower than that in developed countries, the former will experience faster growth rates than the later.

The theoretical literature consulted above clearly indicates that developing countries benefits more when they engage in trade with technologically advanced economies. However, the trade-growth nexus could be weak in developing countries if the comparative advantage theory is poorly understood and insufficiently implemented, for example, according to World Bank [2], developing economies do not derive significant benefits by engaging in the exporting of unprocessed products to developed countries. Therefore, developing countries need to embrace the value-addition concept in order to benefit significantly from trade and maintain sustainable levels of growth.

The trade-growth relationship is also supported by a number of previous studies with no consensus on this important hypothesis. Prominent of these is a study by Kim and Lin [16] who applied the instrument-variable threshold regression methodology to 61 selected developing countries. Their results confirmed an income threshold level of $41.5 \%$, above which greater trade enhances economic growth by an average of $12.4 \%$. Below the threshold level, however, trade openness has detrimental effects on growth of about $14.2 \%$. Contrary to these findings, Afzal and Hussain [17] found no causal relationship between trade (exports and imports) and economic growth in Pakistan. Surprisingly, this finding has been challenged by Klasra [18] and Shahbaz [19] using the Generalized Method of Moments (GMM) estimator on panel datasets of Pakistan and Ghana, found evidence that a unit increase in trade translates to an average of $24.6 \%$ increase in economic growth in Pakistan, but the trade-growth hypothesis was found to be weak in the case of Ghana.
The real effect of trade openness on economic growth also depends on the specific country circumstances, the geo-political characteristics and the general financial depth of an economy. In another study, Frankel and Romer [6] found that trade openness generates higher income levels in a cross section of 63 countries, the BRICS included. Other previous studies that supports the trade-growth nexus include Dollar and Kraay [11]. Similarly, Bolaky [20] used cross-country data from 126 countries and concluded that trade openness has a positive impact on per capita income. Kim et al. [21] provide evidence that the trade-growth link is positive in high-income, low-inflation, and nonagricultural economies, vice versa. In a different study, Huang and Chang [1] found that trade openness promotes economic growth only when an economy approaches an average of between $47 \%$ to $63 \%$ threshold level of stock market development. In a sample of 115 developing economies, Sakyi, et al. [22] employed the ARDL methodology and their results pinpointed to a positive bi-directional causal relationship between trade and economic growth in these economies, the BRICS nations included in the sample.

\section{Theoretical Framework and Methodology}

Considering the conventional growth literature, we specify a growth model that was initially developed by Paul [23] and also the extended version and recently employed by Keho [12]. Economic growth and its determinants which vary across time and economies is specified as follows:

$$
\ln Y_{i t}=\alpha_{0}+\mathrm{d} \ln Y_{i t-1}+\beta^{\prime} \ln X_{i t}+l i+m_{t}+e_{i t}
$$

Where, $\ln y_{i t}$ is the logarithm of real GDP per capita (a proxy of economic growth) of country $i$ in period $t$. The initial GDP per capita is represented by $Y_{i t-1}$ and $X_{i t}$ denotes the determinants of $\ln Y_{i t}$, defined according to the augmented Solow growth model. $\lambda_{i}$ is a proxy of unobserved country specific effects, and $\mu_{t}$ represents the unobserved time specific effects that captures any global shocks, and $\varepsilon_{i t}$ is the error correction term. Therefore, the econometric model employed in this study take the form:

$\ln Y i t=\beta_{0}+\beta_{1} Y_{i t-1}+\beta_{2} \ln$ Openness ${ }_{i t}+\beta_{3}\left(\right.$ InOpenness $\left._{i t}{ }^{*} \ln Y_{i t-1}\right)+\beta_{4} K_{i t}+\beta_{5} L_{i t}$ $+\beta_{6} E x_{i t}+\beta_{7} F D I_{i t}+l i+m_{t}+e_{i t}$

\section{Variables, data and expected a priori}

The dataset of this study covers a panel of five countries in the BRICS community for the period from 1990 to 2017 . The selection of this data period facilitates the analysis of the pre- and the post economic performance of the BRICS countries in relation to the trade-growth link. The data was extracted from two sources, namely, the BRICS Development Bank data base and the World Bank.

The initial GDP per capita is denoted by $Y_{i t-1}$ and based on the conditional convergence hypothesis, the coefficient of this variable is expected to be negative and significant. This is because, according to Barro and Martin [3], the law of diminishing marginal returns on capital asserts that economies with lower GDP per capita are expected to experience faster growth rates than those with higher per capita GDP. The coefficient of trade openness (ratio of exports and imports to GDP), InOpenness , is predicted to be negative or positive because there exists ambiguous empirical evidence on the trade-growth link in the literature [12]. The interaction term between openness and country's initial income level, $\ln$ Openness ${ }_{i p}{ }^{*} \ln Y_{i t-1}$ is included in the model to determine whether economic growth is conditioned by the initial income level of the economy due to trade openness and which economies tend to benefit more from trade openness. The coefficient of physical capital 
accumulation, $\mathrm{K}_{\mathrm{it}}$, is expected to be positive. This variable is proxied by the share of gross fixed capital formation to GDP per capita. The variable of labour force or economically active economically active population, $\mathrm{L}_{\mathrm{it}}$, is expected to have negative or positive impact on growth [24]. The coefficients of foreign direct investment and real exchange rate, $F D I_{i t}$, and $E x_{i t}$ respectively, are expected to be negative or positive [25].

\section{Estimation techniques}

The empirical analysis utilised in this study comprises of three steps. The first step examines the stationarity of the variables using the panel tests of unit root, namely, the Levin, Lin and Chu (LLC) test and the Im, Pesaran and Shin (IPS) test. The second step tests the long run relationships between the variables by employing the bounds method of cointegration that was developed by Pesaran et al., [26]. The appealing features of this approach in cointegration testing are well documented in the econometric literature. For one, it allows the analysis of variables that are $\mathrm{I}(0)$ or $\mathrm{I}(1)$, but with non that are $\mathrm{I}(2)$. This circumvents the problem associated with low power and conflicting results of the conventional tests of unit root. The ARDL tests of cointegration further solves the endogeneity problems and the inability to test hypotheses on the estimated coefficients in the long-run associated with the EngleGranger two-step method. For these reasons, we use the ARDL bounds test to investigate the short run and the long run relationship between trade openness and economic growth in the BRICS countries. The third step is to carry out the causal relationships among the variables using the Granger causality tests.

According to Gujarati [27], the point of departure when utilizing and setting up the bounds test is to specify the following unrestricted vector autoregressive (VAR) in levels:

$$
Y_{i t}=\mu_{t}+\sum_{j=1}^{p} \Phi_{j} Y_{i t-j}+\varepsilon_{i t}
$$

Where, $Y_{i t}$ is equivalent to $\left[i_{i p}, \Pi_{i t}\right]$, and the vector of error terms, $\varepsilon_{i t}=\left[\varepsilon_{p}, \varepsilon_{\Pi}\right] \sim N(0, \delta)$, where $\delta$ is positive and defined by:

$$
\delta=\left\{\begin{array}{c}
\varphi_{i i} \varphi_{i \pi} \\
\varphi_{i \pi} \varphi_{\pi \pi}
\end{array}\right\}
$$

If we manipulate the VAR model specified in formulation (iii) the following vector error correction (VEC) model is obtained:

$$
\Delta Y_{i t}=\mu_{i t}+\lambda Y_{i t-1}+\sum_{j=1}^{p-1} y_{j} \Delta Y_{t-j}+\varepsilon_{i t}
$$

Where the short run coefficients are denoted as:

$$
-\sum_{k=j+1}^{p} \Phi_{k}=y_{j}=\left[\begin{array}{ll}
y_{i i, j} & y_{i \pi, j} \\
y_{\pi j} & y_{\pi \pi, j}
\end{array}\right]
$$

The coefficient $\lambda$ represents the long-run multiplier matrix and takes the form:

$$
\lambda=\left[\begin{array}{ll}
\lambda_{i i} & \lambda_{i \pi} \\
\lambda_{\pi i} & \lambda_{\pi \pi}
\end{array}\right]=-\left(I_{2}-\sum_{j=1}^{p} \Phi_{j}\right)
$$

Where $I_{2}$ denotes a $2 \times 2$ matrix identity and the diagonal elements of the matrix $\lambda$ are left unrestricted. This accommodates the possibility that the variables could be either I( 0$)$ or I( 1 ). Another appealing feature of the bounds test approach is that it allows the testing of at most one long-run relationship between the variables and as such requires a zero restriction on one of the diagonals of the matrix $\lambda$. To test for the cointegration between the variables, we restrict the lagged levels variables and intercept in formulation (ii), that is, $\beta_{0}=\beta_{1}=\beta_{2}=\beta_{3}=\beta_{4}=\beta_{5}=\beta_{6}$ $=\beta_{7}=0$. This hypothesis is tested through the mean of the F-test. For large samples like the dataset of the BRICS countries, the asymptotic critical values are provided by Pesaran et al. (2001), by suggesting the application of the cumulative sum of recursive residuals (CUSUM) and the cumulative sum of recursive of squares of recursive residuals (CUSUMSQ) tests to measure the parameter reliability of the model.

\section{Empirical Results And Discussion}

The first stage of our empirical analysis involves the analysis of the descriptive statistics of the series to determine the distribution, skewness and kurtosis of the data as displayed in Table 1.

According to Brooks [28], the flatness or the peak of the distribution of the series is known as kurtosis. A normally distributed series has a kurtosis of 3 and when the value is less than 3 , then the series has a platykurtic (flat) distribution relative to the normal distribution. If the kurtosis is greater than 3 , then the series has a leptokurtic (peaked) distribution relative to the normal. It can be seen from Table 1 that all the variables have a leptokurtic distribution relative to the normal, in exception of South Africa with a platykurtic distribution relative to normal. Another important descriptive statistic is the skewness of the series, that is, how the series is distributed around its mean. Brooks [28] maintains that a normally distributed series has a skewness of zero. The skewness of the series can be either positive or negative. The former entails a long right-tail distribution and the later implies a long left-tail distribution. According to Table 1, all the series have a long right-tail distribution. This means that the null hypothesis of normal distribution cannot be rejected for the variables of these economies. In addition, the Jarque-Bera values of all the countries is greater than the $5 \%$ level of significance, meaning that we accept the null hypothesis of normal distribution of the series.

The following step of our empirical analysis is the testing of the order of integration of the series using the panel unit root tests [26]. This stage is important because the ARDL bounds test requires the regressand variable to be $\mathrm{I}(1)$ and the regressors to be $\mathrm{I}(0)$ or $\mathrm{I}(1)$. Should any of the variables be I(2) or more, then the results of the F-test will be biased. The results of the panel unit root tests are reported in Table 2. All the panel unit root tests utilised indicate that the variables are $\mathrm{I}(0)$ processes, thus, satisfying the pre-condition to confidently employ the bounds cointegration test.

Having established the order of integration of the variables, we proceed to apply the bounds test to empirically determine the long run relationship between the variables. The results of this test are reported in Table 2 . Since the bounds cointegration test is typically sensitive to the optimal lag order criterion utilised, in this study we make use of the

\begin{tabular}{|l|c|c|c|c|c|}
\hline Variables & Brazil & Russia & India & China & South Africa \\
\hline Mean & 17.813 & 23.616 & 7.913 & 3.932 & 10.081 \\
\hline Median & 15.781 & 13.054 & 6.84 & 2.840 & 9.333 \\
\hline Maximum & 45.621 & 160.623 & 12.35 & 12.620 & 21.686 \\
\hline Minimum & 7.182 & 5.437 & 7 & 1.001 & 5.000 \\
\hline Std. Dev. & 7.813 & 25.743 & 1.945 & 2.904 & 4.116 \\
\hline Skewness & 1.451 & 2.872 & 1.803 & 1.564 & 0.587 \\
\hline Kurtosis & 6.043 & 11.803 & 3.242 & 5.783 & 2.426 \\
\hline Jarque-Bera & 114.523 & 1005.032 & 40.504 & 216.632 & 16.554 \\
\hline Probability & 0 & 0.000 & 0.000 & 0.001 & 0.007 \\
\hline Observations & 247 & 247 & 247 & 247 & 247 \\
\hline
\end{tabular}

Source: Author's computation using E-views 8 Econometric Software.

Table 1: Descriptive statistics of variables. 
general-to-specific modelling method of Ali et al. [29] and the Akaike Information Criterion (AIC) to determine the optimal lag structure as $\mathrm{p}=4$. The results reported in Table 2 were obtained using lag structure $\mathrm{p}=4$ of the calculated F-statistics testing the null hypothesis of no cointegration against the alternative that there is long run relationship (cointegration).

The F-statistics are computed with trade openness and economic growth interchangeably used as a regressand variable in the ARDL regression. According to the results exhibited in Table 3, the null hypothesis of no cointegration cannot be accepted, rather we reject the null hypothesis and accept the alternative hypothesis that there is a long run relationship between the variables. The existence of cointegration between economic growth, trade openness, capital and labour, conforms with the propositions of the endogenous growth theories and moreover corroborate with the previous findings of Kim and Lin [16], Shahbaz [19], Sakyi et al. [22] however, disputes the findings of Afzal and Hussain [17], who found no long run relationship between growth and trade openness in Pakistan. Looking in the case of South Africa, a unit change in trade openness results in an average of about $47 \%$ increase in output growth which is fairly higher than the finding of Shahbaz [19] who concluded that a unit change in openness to trade translates to about $24.6 \%$ increase in economic growth in Pakistan, but found the trade-growth hypothesis to be weak in the case of Ghana. However, Table 3 indicates that South Africa and Brazil still lag behind

\begin{tabular}{|c|c|c|}
\hline Tests & t-statistic & P-value \\
\hline aIPS & -3.453 & $0.005^{* * *}$ \\
\hline${ }^{\text {bADF-Fisher Chi-square }}$ & 108.4 & $0.003^{* * *}$ \\
\hline${ }^{\text {cPP- Fisher Chi-square }}$ & 82.43 & $0.028^{* *}$ \\
\hline d $L L C$ & -5.613 & $0.001^{\text {** }}$ \\
\hline
\end{tabular}

Note: $\mathrm{a}, \mathrm{b}, \mathrm{CH} 0=$ Each series contains unit root, $\mathrm{dH} 0=$ Common unit root process; Significance @ $1 \%, 5 \%$ and $10 \%$ is indicated by **, and *** respectively.

Source: Author's computation using E-views 8 Econometric Software. Table 2: Panel unit root tests.

\begin{tabular}{|c|c|c|c|c|c|c|c|}
\hline Country & F-stats & t-stats & $\begin{array}{l}5 \% \\
1(0)\end{array}$ & $I(1)$ & $\begin{array}{l}10 \% \\
1(0)\end{array}$ & $I(1)$ & $\begin{array}{c}\text { B } \\
\text { ( } \Delta \text {-method })\end{array}$ \\
\hline Brazil & 2.595 & -2.061 & 4.86 & 5.82 & 4.40 & 4.76 & 0.539 \\
\hline Russia & $4.323^{*}$ & 1.405 & 6.92 & 7.50 & 5.60 & 6.93 & $1.365^{*}$ \\
\hline India & 13.817 & $-5.316^{*}$ & 4.87 & 5.94 & 4.32 & 4.89 & $0.787^{*}$ \\
\hline China & 5.689 & -2.168 & 6.86 & 7.40 & 5.75 & 6.84 & $1.353^{*}$ \\
\hline outh Africa & 2.051 & -2.336 & 4.98 & 7.29 & 6.24 & 6.79 & $0.470^{*}$ \\
\hline
\end{tabular}

Notes: The critical value bounds F-stats are Pesaran et al. (2001). $\beta$ denotes the long run coefficient. *signifies significance at the $5 \%$ level of significance.

Source: Author's computation using E-views 8 Econometric Software.

Table 3: Bounds test cointegration results. in terms of the magnitude in which openness to trade stimulates economic growth. The highest trade-growth link, according to Table 3 , is found in the case of China, with a $1 \%$ change in trade openness resulting in an average of $135 \%$ increase in economic growth, making China to be amongst the leading economies in trade and growth among the developing and developed world economies.

The results of the short run and the long run causality of the variables are reported in Table 4. Emphasis is greatly given to the causal relationship between trade openness and economic growth in the BRICS countries.

Table 4 exhibit evidence that the coefficients on the error correction term t-statistics $\left(\mathrm{ARDL}_{\mathrm{t}-1}\right)$, are highly significant in exception of India when economic growth is the dependent variable. We can, therefore, confidently infer that there is a bi-directional causality between trade openness and economic growth in the long term in the BRICS countries. It is also clear from Table 4 that there is evidence of unidirectional longrun causality from economic growth to trade openness especially in the case of China and Russia. Our findings in this case are in line with Frankel and Romer [6], Dollar and Kraay [11] and Bolaky [20].

In addition to the above econometric tests, we also checked the stability of the ARDL regression model by utilising the cumulative sum (CUSUM) and the cumulative sum of squares (CUSUMSQ) tests as proposed by Brown [30]. The plots of these tests lie within the $5 \%$ critical bound, hence, providing evidence that the variables and their parameters do not suffer from any form of structural instability for the study period [31-33]. The residual diagnostic tests revealed that the observed $R^{2}$ is greater than $5 \%$ level of significance, therefore, we fail to reject the null hypotheses that there is no serial correlation and traces of heteroskedasticity in the model. Moreover, the model was found to be acceptable and stable since the $R^{2}=89 \%$ is greater than the standard of $60 \%$.

\section{Conclusion and Policy Implications}

This paper was an empirical attempt to investigate the relationship between trade openness and economic growth in the BRICS countries. It is evident from the existing empirical literature that there is no consensus on the trade-growth link and the results are mixed across countries, data and empirical techniques. In order to carry out this study, several econometric tests were performed. Firstly, since panel data was utilised, we were obliged to employ panel unit root tests, namely, the LL and the IPS tests. The results reported from these panel unit root tests revealed that the variables are $\mathrm{I}(0)$ processes, therefore, we proceeded to apply the bounds method of cointegration and the Granger causality test. The presence of a long run relationship between

\begin{tabular}{|c|c|c|c|c|c|c|}
\hline \multirow[t]{2}{*}{ Country } & \multirow[t]{2}{*}{ Null Hypothesis } & \multicolumn{3}{|c|}{ Short run causality } & \multicolumn{2}{|c|}{ Long run causality } \\
\hline & & F-stats & P-values & $\sum$ Coefficient & $\operatorname{ARDL}_{t-1}$ & t-stats \\
\hline Brazil & $\begin{array}{l}\mathrm{H}_{0}: \text { Open }>>Y \\
\mathrm{H}_{0}: \mathrm{Y}>>\text { Open }\end{array}$ & $\begin{array}{l}0.028 \\
0.017\end{array}$ & $\begin{array}{l}0.860 \\
0.666\end{array}$ & $\begin{array}{l}- \\
-\end{array}$ & $\begin{array}{l}-0.242^{*} \\
-0571^{*}\end{array}$ & $\begin{array}{l}-2.116 \\
-3.381\end{array}$ \\
\hline Russia & $\begin{array}{l}\mathrm{H}_{0}: \text { Open>>Y } \\
\mathrm{H}_{0}: \mathrm{Y}>>\text { Open }\end{array}$ & $\begin{array}{l}6.355^{*} \\
3.022^{*}\end{array}$ & $\begin{array}{l}0.000 \\
0.035\end{array}$ & $\begin{array}{l}-0.526 \\
-4.316\end{array}$ & $\begin{array}{l}-0.142^{*} \\
-0.886^{*}\end{array}$ & $\begin{array}{l}-4.238 \\
-4.221\end{array}$ \\
\hline India & $\begin{array}{l}\mathrm{H}_{0}: \text { Open }>>Y \\
\mathrm{H}_{0}: \mathrm{Y}>>\text { Open }\end{array}$ & $\begin{array}{l}0.735 \\
0.070\end{array}$ & $\begin{array}{l}0.361 \\
0.910 \\
\end{array}$ & - & $\begin{array}{c}- \\
-0.553^{*}\end{array}$ & $-\overline{-}$ \\
\hline China & $\begin{array}{l}\mathrm{H}_{0}: \text { Open }>>Y \\
\mathrm{H}_{0}: \mathrm{Y}>>\text { Open }\end{array}$ & $\begin{array}{c}4.673^{*} \\
0.058\end{array}$ & $\begin{array}{l}0.038 \\
0.821\end{array}$ & $\begin{array}{l}-0.280 \\
-0.175\end{array}$ & $\begin{array}{l}-0.571^{*} \\
-0.418^{*}\end{array}$ & $\begin{array}{l}-5.418 \\
-1.753 \\
\end{array}$ \\
\hline South Africa & $\begin{array}{l}\mathrm{H}_{0}: \text { Open }>>\mathrm{Y} \\
\mathrm{H}_{0}: \mathrm{Y}>>\text { Open }\end{array}$ & $\begin{array}{c}2.501^{*} \\
0.013\end{array}$ & $\begin{array}{l}0.032 \\
0.621\end{array}$ & $\begin{array}{c}-0.2160 \\
-\end{array}$ & $\begin{array}{l}-0.310^{*} \\
-0.221\end{array}$ & $\begin{array}{l}-3.218 \\
-1.650\end{array}$ \\
\hline
\end{tabular}

Source: Author's computation using E-views 8 Econometric Software.

Table 4: Granger causality test results. 
Citation: Shayanewako VB (2018) The Relationship between Trade Openness and Economic Growth: The Case of BRICS Countries. J Glob Econ 6: 289. doi: 10.4172/2375-4389.1000289

Page 5 of 5

the variables, especially trade openness and economic growth, was confirmed by the results of the cointegration test. As such, evidence from the bounds test of cointegration indicated that there exists a bidirectional causality from trade openness to economic growth in almost every BRICS country. The results further report that there is evidence of unidirectional causality between trade openness and output growth, particularly in the case of China.

The policy implications of this study are that cooperation between these family of countries play a critical role in accelerating trade within themselves and the rest of the international community. This is not only a requirement to strengthen trade relations and capital flows but also a safe choice for the five economies to grow together through enlarged openness to trade opportunities. These countries should also place great emphasis on infrastructural development through the financial opportunities of the BRICS development Bank and fully utilise the myriad of import and export opportunities that are presented by the collaborative efforts of these economies. Moreover, the BRICS countries should also consider the adoption of a common currency to easily finance trade between countries in the long term. In spite of the promising results of this study, we contend that this paper provides only a promising step towards developing a more comprehensive empirical research which could perhaps include more variables, data and empirical techniques typical for robust results on this issue.

\section{References}

1. Huang LC, Chang SH (2014) Revisit the nexus of trade openness and GDP growth: Does the financial system matter? J Int Trade Econ Develop 23: 10381058.

2. World Bank (2015) The East Asian miracle: Economic growth and public policy. New York, NY: Oxford University Press.

3. Barro RJ, Martin XS (1995) Technological diffusion, convergence, and growth J Econ Growth 2: 1-26.

4. RiveraBatiz LA, Romer PM (1992) International Trade with Endogenous Technological Change. Eur Econ Rev 35: 971-1001.

5. Edwards S (1998) Openness, productivity and growth: What do we really know? Econ J 108: 383-398.

6. Frankel JA, Romer D (1999) Does trade cause growth? Am Econ Rev 89: 379399

7. Stiglitz JE (1996) Some lessons from the East Asian miracle. The World Bank Research Observer 11: 151-177.

8. Cooke HA (2010) Trade policy and economic growth in Sub-Saharan Africa: A panel data approach. Am J Trade Policy 1: 94-101.

9. Haussmann R., Hwang J, Rodrik D (2007) What you export matters. J Econ Growth 12:1-25.

10. Jafari SA, Ghaderi S, Hosseinzadeh R, Nademi $Y$ (2012) Openness and inflation: New empirical panel data evidence. Econ Lett 117: 573-577.

11. Dollar D, Kraay A (2004) Trade, Growth and Poverty. Econ J 114: 22-49.
12. Keho $Y$ (2017) The impact of trade openness on economic growth: The case of Cote d'Ivoire. Cogent Econ Financ 5: 133-820

13. Markus B, Daniel L (1978) Trade openness and economic growth: Panel data evidence from Sub-Saharan Africa. Economica 82: 1302-1323.

14. Grossman GM, Helpman E (1991) Comparative Advantage And Long-Run Growth. Am Econ Rev 80: 796-815.

15. Romer PM (1994) Endogenous technological change. J Polit Econ 98: 71-102.

16. Kim DH, Lin S (2009) Trade and growth at different stages of economic development. J Development Stud 45: 1211-1224.

17. Afzal M, Hussain I (2010) Export led growth hypothesis: Evidence from Pakistan. J Quant Econ 8: 130-147.

18. Klasra MA (2011) Foreign direct investment, trade openness and economic growth in Pakistan and Turkey: An investigation using bounds test. Qual Quant 45: 223-231.

19. Shahbaz M (2012) Does trade openness affect long-run growth? Cointegration causality and forecast error variance decomposition tests for Pakistan. Econ Model 29: 2325-2339.

20. Bolaky AM (2008) The Trade-Growth Link Revisited: The Case of Bangladesh The Journal of Economics 44: 701-727.

21. Kim DH, Lin SC, Suen YB (2012) The simultaneous evolution of economic growth, financial development and trade openness. J IntTrade Econ Development 21: 513-537.

22. Sakyi D, Villaverde J, Maza A (2015) Trade openness, income levels, and economic growth: The case of developing countries 1970-2009. J Int Trade Econ Development 24: 860-882.

23. Paul R (1956) New Goods, Old Theory, and The Welfare Costs Of Trade Restrictions. J Development Econ 43: 5-38.

24. Qazi Muhammad AH, Shahida W, Wee YL (2009) The impact of trade openness on economic growth in China: An empirical analysis. J Asian Financ, Econ Bus 3: 27-37.

25. Roberto C, Linda K, Norman VL (2005) Openness can be good for growth: The role of policy complementarities. Journal of Development Economics 90: 33-49.

26. Pesaran H, Shin $\mathrm{Y}$, Smith RJ (2001) Bounds testing approaches to the analysis of level relationships. J Ap Econometrics 16: 289-326.

27. Gujarati DN (2004) Basic Econometrics. 4th ed. New York: McGraw Hill.

28. Brooks C (2008) Introductory To Econometrics For Finance. Cambridge: Cambridge University Press.

29. Ali P, Muhammed S, ljaz UR, Saqlin LS (1982) Revisiting linkages between financial development, trade openness and economic growth in South Africa: Fresh evidence from combined cointegration test. Qual Quan 49: 785-803.

30. Brown T (1975) Statistical Inference in Vector Auto Regressions with Possibly Integrated Processes. J Econ 66: 225-250.

31. Almeida R, Fernandes AM (1995) Openness and technological innovations in developing countries: Evidence from Firm-Level Surveys. J Development Stud 44: 701-727.

32. Mohsen BO, Farhang N (1999) Openness and economic growth: An empirical investigation. Ap Econ Lett 6: 557-561.

33. Cheng W, Xiaming L, Yingqi W (1995) Impact of openness on growth in different country groups. The W Econ $27: 567-585$ 